\title{
KONFLIK INTERNAL PARTAI NASDEM DAN PEMILIHAN LEGISLATIF 2014
}

\author{
Yunicha Diana dan Robi Cahyadi Kurniawan \\ Alumni Jurusan Ilmu Pemerintahan FISIP Universitas Lampung \\ E-mail: Ichadiana709@gmail.com ; robicahyadi9@gmail.com
}

\begin{abstract}
After election commission passed Nasdem Party to participate in the 2014 elections, the party is now headed by Surya Paloh reap discord. The split was marked by the release of Hary Tanoe Soedibjo, Chairman of the Board of Expert Nasdem Party. Hary Tanoe addition, Secretary-General Ahmad Rofik, Saiful Haq Deputy SecretaryGeneral, and the Chairman of the Internal DPP Nasdem Tirtana Endang also resigned from the party Nasdem. The resignation was caused by disagreement with Surya Paloh who plans to overhaul the management of board center. The purpose of this study was to determine the Internal Conflict and Imaging Nasdem Political Party In Legislative Election Year 2014. The method used in this research is descriptive qualitative. The types of data used in this study is primary data and secondary data. Primary data were obtained from in-depth interviews, and secondary data obtained through these documents. The result of internal conflict Nasdem a conflict of interest due to the race for Chairman Nasdem between Surya Paloh and Hary Tanoe Sudibjo. This conflict resulted in the resignation Hary Tanoe and followed by Nasdem cadres in several regions in Indonesia. Nasdem administrators in several regions in Indonesia who resigned are who support Hary Tanoe. Impact in the community is its lack of public confidence in Nasdem as new party that is expected to bring positive change. So that tis conflict can interfere with imaging Nasdem the 2014 Elections.
\end{abstract}

Key words: Nasdem, Internal conflict, imaging, legislative election in 2014

\begin{abstract}
ABSTRAK
Setelah Komisi Pemilihan Umum meloloskan Partai Nasdem untuk bisa berpartisipasi dalam Pemilu tahun 2014, Partai yang kini diketuai oleh Surya Paloh menuai perpecahan. Perpecahan itu ditandai dengan keluarnya Harry Tanoe Soedibjo, Ketua Dewan Pakar Partai Nasdem. Pengunduran diri ini disebabkan oleh karena tidak sepaham dengan Surya Paloh yang berencana merombak kepengurusan Dewan Pimpian Pusat Nasdem. Tujuan penelitian ini adalah untuk mengetahui Konflik Internal Partai Nasdem dan Pencitraan Politik Pada Pemilihan Legislatif Tahun 2014. Metode yang digunakan dalam penelitian ini adalah deskriptif kualitatif. Jenis data yang digunakan dalam penelitian ini adalah data primer dan data sekunder. Data primer didapat dari wawancara mendalam, sedangkan data sekunder didapat melalui dokumen-dokumen. Hasil penelitian konflik internal Partai Nasdem merupakan konflik kepentingan yang disebabkan adanya perebutan kursi Ketua Umum Nasdem antara Surya Paloh dan Hary Tanoe Sudibjo. Konflik ini mengakibatkan mundurnya Hary Tanoe dan diikuti oleh kader-kader Nasdem di beberapa wilayah di Indonesia. Pengurus Nasdem di beberapa daerah di Indonesia yang mengundurkan diri adalah orang-orang yang menjadi pendukung Hary Tanoe. Dampak dalam masyarakat adalah kurangnya rasa kepercayaan masyarakat pada Nasdem sebagai partai baru yang diharapkan bisa membawa perubahan positif. Sehingga konflik ini dapat mengganggu pencitraan Nasdem pada pemilihan legislatif 2014.
\end{abstract}

Kata kunci: Nasdem, konflik internal, pencitraan politik, pemilihan legislatif 2014 


\section{PENDAHULUAN}

Partai-partai politik adalah aktor-aktor utama di dalam sistem yang menghubungkan antara kewarganegaraan dengan proses pemerintahan. Partai politik merupakan perantara yang besar yang menghubungkan kekuatankekuatan dan ideologi-ideologi sosial dengan lembaga-lembaga pemerintahan yang resmi dan yang mengaitkannya dengan aksi politik yang lebih luas di dalam masyarakat. Negara yang tidak memiliki partai politik dapat disebut sebagai Negara yang tidak memiliki sarana kelembagaan guna mendorong perubahan yang terus menerus, dan menyerap segala impak perubahan yang terjadi dalam masyarakat (Huntington, 1983: 263).

Konflik internal memang akan sering terjadi dalam perjalanan suatu organisasi, karena organisasi merupakan lahan potensial bagi tumbuhnya konflik. Partai politik menjadi salah satu organisasi potensial tersebut, dan partai politik merupakan organisasi yang mempunyai basis massa sangat besar. Konflik internal di beberapa partai, sering terjadi akhir-akhir ini. Kecenderungan terjadinya konflik internal partai politik semakin meningkat baik di tingkat pusat maupun di tingkat daerah. Persamaan kehendak dan cita cita yang menyatukan anggota partai, namun partai politik tidak akan bisa menghindari terjadinya konflik. Konflik internal partai politik disebabkan banyak hal, salah satunya tidak ada kesamaan kehendak dan cita cita atau karena anggota partai yang tidak percaya akan kepemimpinan pemimpinnya.

Salah satu partai politik yang kini sedang hangat diperbincangkan adalah Partai Nasional Demokrat (Nasdem). Partai Nasdem dideklarasikan Surya Paloh pada tanggal 1 Februari 2010. Mantan Ketua Dewan Pembina Partai Golkar ini mendirikan Nasdem sebagai organisasi yang menginginkan perubahan dan kemajuan bangsa. Partai Nasdem akhirnya dinyatakan oleh Kementerian Hukum dan HAM lolos sebagai parpol baru yang berhak mengikuti Pemilu 2014. Partai Nasdem juga Mendapatkan nomor urut 1 , dan menjadi satu-satunya parpol pendatang baru pada pesta demokrasi 2014 nanti (http://www.partaiNasdem.org/2011/11/18/ menerka-peluang-partai-Nas dem-dipemilu-2014/).
Konflik perpecahan dalam Partai Nasdem akan sangat mempengaruhi partisipasi masyarakat dalam pemilihan legislatif Tahun 2014 mendatang. Dampak dari Konflik internal yang terjadi pada Partai Nasdem adalah persepsi dan tingkat kepercayaan masyarakat pada Partai Nasdem dinilai akan berkurang, karena dengan kemunduran itu perpecahan di internal partai menjadi mencuat dan otomatis menjadi konsumsi publik. Konflik internal partai Nasdem tidak baik di mata masyarakat. Nasdem membutuhkan strategi baru untuk meyakinkan masyarakat agar tetap percaya dengan gagasan restorasi yang diusung partai Nasdem. (http:// www.rimanews.com/read/20130122/89193/ pengamat-sayangkan-perpecahan-di-partaiNasdem-hary-tanoe-gagalkan-konsep).

Daftar Penduduk Potensial Pemilih Pemilu (DP4)Kota Metro pada Tahun ini adalah sebanyak 116.109 jiwa, terjadi penambahan sebesar 13.998 jiwa dibandingkan dengan DPT Pilkada 2010 (http://lampung.tribunnews.com./m/index. php//2013/02/07/dp4-kota-metro-116.109jiwa). Penambahan Daftar pemilih Tetap di Kota Metro menunjukkan bahwa tingkat partisipasi masyarakat Kota Metro dalam pemilihan umum mengalami penambahan yang cukup besar.

\section{KERANGKA TEORETIK}

Penulis menggunakan teori Partai politik menurut Sigmund Neuman, mengemukakan definisi partai sebagai berikut: " partai politik adalah organisasi dari aktivitas-aktivitas politik yang berusaha untuk menguasai kekuasaan pemerintah serta merebut dukungan rakyat atas dasar persaingan dengan suatu golongan atau golongan-golongan lain yang mempunyai pandangan yang berbeda (Budiardjo, 2003:161). MenurutMauriceDuverger(Darmastuti, 2004:5) istilah partai digunakan untuk menggambarkan faksi-faksi dalam republik-republik masa lalu, pasukan-pasukan yang terbentuk disekitar conditeri pada masa Renaisans Itali, kelab-kelab tempat berkumpul anggota-anggota dewan revolusi, komite-komite yang bertugas memenangkan pemilihan umum dalam monarki konstitusional, dan organisasi sosial yang membentuk opini public dalam Negara-negara demokrasi modern. Semua lembaga tersebut berperan dalam memenangkan kekuasaan politik dan menerapkannya. 
Fungsi Partai Politik menurut Pasal 7 Undang-Undang Nomor 2 Tahun 2011 adalah:

1. Pendidikan politik bagi anggotanya dan masyarakat luas agar menjadi warga Negara Republik Indonesia yang sadar akan hak dan kewajibannya dalam kehidupan bermasyarakat, berbangsa, dan bernegara;

2. Penciptaan iklim yang kondusif dan program konkrit serta sebagai perekat persatuan dan kesatuan bangsa untuk mensejahterakan masyarakat;

3. Penyerap, penghimpun dan penyalur aspirasi masyarakat secara konstitusional dalam merumuskan dan menetapkan kebijakan Negara;

4. Partisipasi politik warga Negara; dan

5. Rekrutmen politik dalam proses pengisian jabatan politik melalui mekanisme demokrasi dengan memperhatikan kesetaraan gender.

Clinton F. Fink (Kartono, 2009: 246) mendefinisikan konflik sebagai berikut:

1. Konflik ialah relasi-relasi psikologis yang antagonistis, berkaitan dengan tujuan-tujuan yang tidak bisa disesuaikan interest-interest ekslusif dan tidak bisa dipertemukan, sikapsikap emosional yang bermusuhan, dan struktur-struktur nilai yang berbeda.

2. Konflik adalah interaksi yang antagonistis, mencakup "tingkah laku lahiriah yang tampak jelas, mulai dari bentuk-bentuk perlawanan halus, terkontrol, tersembunyi, tidak langsung, sampai pada bentuk perlawanan terbuka, kekerasan perjuangan tidak terkontrol, benturan laten, pemogokan, huruhara, maker, gerilya, perang, dan lain-lain".

Konflik menurut Soekamto (1984: 63) sering diartikan sebagai suatu proses sosial di mana setiap individu atau kelompok berusaha untuk memenuhi tujuannya dengan jalan menentang pihak lawan yang terkadang disertai ancaman atau kekerasan.

Menurut Surbakti (1992: 153), konflik politik dikelompokkan menjadi dua tipe, yaitu:

1. Konflik positif, yaitu konflik yang tak meng-ancam eksistensi sistem politik, yang biasanya disalurkan lewat mekanisme penyelesaian konflik yang disepakati bersama dengan konstitusi. Mekanisme yang dimaksud ialah lembaga-lembaga demokrasi, seperti partai politik, badan-badan perwakilan rakyat, pengadilan, pemerintah, pers, dan forum-forum terbuka yang lain. Tuntutan akan perubahan yang diajukan oleh sejumlah kelompok masyarakat melalui lembagalembaga itu merupakan contoh konflik positif

2. Konflik negatif ialah konflik yang dapat mengancam eksistensi sistem politik yang biasanya disalurkan melalui cara-cara nonkonstitusional, seperti kudeta, separatism, terorisme, dan revolusi. Apabila mayoritas masyarakat memandang lembaga dan struktur yang ada tidak mencerminkan kepentingan umum maka konflik yang disalurkan melalui mekanisme politik justru dipandang sebagai konflik negatif.

\section{METODE PENELITIAN}

Tipe penelitian yang digunakan adalah tipe penelitian deskriptif dengan pendekatan kualitatif yaitu dalam penelitian ini penulis berusahamenggambarkan ataumendeskripsikan secara terperinci tentang bagaimana konflik yang terjadi pada Partai Nasdem terhadap pencitraan politik pada pemilihan legislatif tahun 2014. Adapun lokasi penelitian adalah di Kecamatan Metro Pusat Kota Metro. Fokus utama penelitian ini adalah konflik internal yang terjadi pada Partai Nasdem, yaitu Konflikkonflik kepentingan yang terjadi dalam partai Nasdem.

Sumber data dalam penelitian ini meliputi: Pertama, data primer adalah data yang diperoleh dengan cara menggali secara langsung dari nara sumber yang merupakan hasil dari teknik pengumpulan data melalui wawancara dan survei. Kedua, Data sekunder adalah data yang diperoleh dari sumber-sumber pendukung selain lokasi penelitian, yang didapat dari literaturliteratur, serta dokumen-dokumen lain yang mendukung dalam penelitian. Sumber informan yang ditentukan dengan cara purposive sampling.

Teknik yang digunakan dalam menentukan informan adalah teknik Purposive Sampling yaitu teknik penentuan informan berdasarkan pertimbangan tertentu (Sugiyono, 2008: 85). Pemilihan informan didasarkan atas subyek yang menguasai permasalahan, dan 
bersedia memberikan data, adapun yang akan dijadikan kunci utama dalam penelitian ini adalah tiga orang pengurus DPD Partai Nasdem Kota Metro, yang terdiri dari Ketua Umum, Wakil Sekretaris Internal, dan Bandahara DPD Nasdem Kota Metro. Selain itu ada 3 informan dari Pakar Politik Universitas Lampung dan masyarakat yang terdiri dari beberapa profesi yaitu: 1 orang Mahasiswa, 1 orang Ibu Rumah Tangga, 2 orang Wiraswasta, 1 orang Kuli Bangunan, dan 1 orang Pegawai Negeri Sipil.

\section{Konflik Internal Partai Nasdem}

Nasional Demokrat merupakan satusatunya partai baru yang menjadi peserta pemilu legislatif 2014 mendatang. Tidak lama setelah Komisi Pemilihan Umum meloloskan Partai Nasdem untuk bisa berpartisipasi dalam Pemilu tahun 2014, partai yang kini diketuai oleh Surya Paloh sudah menuai perpecahan. Perpecahan itu ditandai dengan keluarnya Harry Tanoe Soedibjo, Ketua Dewan Pakar Partai Nasdem. Konfilk internal Partai Nasdem juga mengakibatkan pengunduran diri yang dilakukan oleh beberapa Dewan Pimpinan Wilayah (DPW) yang ada di provinsi-provinsi di Indonesia. Ketua Dewan Pembina (Ormas) Nasional Demokrat (Nasdem), Sri Sultan Hamengku Buwono X juga mundur karena ormas Nasdem kini menjadi partai politik. Penyebab mundur nya para kader partai ini adalah karena ketidak setujuan mereka pada hasil Kongres Partai Nasdem pertama pada 2527 Januari 2013 yang mengangkat Surya Paloh sebagai Ketua Umum Partai Nasdem.

\section{Penyebab Konflik Internal Partai Nasdem}

Pada dasarnya konflik disebabkan karena adanya perbedaan. Konflik bisa muncul dan terjadi pada siapa saja dan kapan saja baik itu konflik antar individu, konflik antar kelompok, konflik antar kelompok dengan negara atau bahkan konflik antar negara. Salah satu bentuk konflik yang dapat terjadi adalah konflik dalam sebuah organisasi. Organisasi terdiri dari berbagai macam unsur yang berbeda dan saling ketergantungan antara satu sama lain demi mencapai suatu tujuan tertentu. Perbedaan dalam satu organisasi inilah yang dapat memunculkan terjadinya konflik. Partai Nasdem merupakan salah satu partai yang sedang mengalami konflik internal. konflik yang terjadi dalam Partai Nasdem adalah konflik kepentingan. Menurut penulis dalam konflik Partai Nasdem, kekuasaanlah yang menjadi aktor utama penyebab terjadinya konflik. Dalam sebuah organisasi termasuk partai politik, konflik akibat kekuasaan merupakan konflik yang sering terjadi.Perebutan kursi ketua umum Nasdem yang terjadi antara Surya Paloh dan Hary Tanoe Sudibjo. Perbedaan pemikiran dan tujuan yang terjadi antara keduanya mengharuskan salah satunya untuk mengundurkan diri dari partai Nasdem. Sebagai salah satu partai Politik yang menjadi peserta pemilu legislatif 2014, Nasdem seharusnya menampilkan citra positif pada masyarakat agar masyarakat dapat mendukung Nasdem dalam pemilu.

\section{Dampak Konflik Internal Partai Nasdem}

Dampak dari konflik Nasdem dirasakan oleh kader Nasdem tidak berpengaruh besar dalam pencitraan politik Nasdem. Para kader yang mengundurkan diri dari kepengurusan partai Nasdem dianggap sebagai orang-orang yang mendukung Hary Tanoe. Sedangkan Surya Paloh memiliki pendukung yang jauh lebih banyak dari Hary Tanoe, karena Surya Paloh sudah lama berkecimpung dalam dunia politik. sedangkan Hary Tanoe adalah orang baru dalam dunia politik. Menurut Budiardjo (2003:163) dan Surbakti (1992:116), salah satu fungsi partai politik adalah partai politik sebagai sarana pengatur dan pengendalian konflik. Konflik ini dapat mengurangi kepercayaan masyarakat pada partai Nasdem sebagai partai baru. Nasdem sebagai partai tidak bisa menjalankan fungsinya dengan baik yaitu sebagai pengatur dan pengendali konflik, partai Nasdem justru mengalami konflik yang mengakibatkan perpecahan dalam partai Nasdem. Konflik-konflik internal partai termasuk konflik internal Partai Nasdem yang terjadi menunjukan bahwa saat ini konflik konflik internal partai sudah menjadi konflik yang sifatnya terbuka. Hal ini karena konflik internal partai menjadi konflik yang hampir semua orang tahu dan keberadaannya terlihat sangat nyata sehingga dapat berdampak pada pembentukan opininegatifdalammasyarakat.

\section{Upaya Partai Nasdem Untuk Menyelesaikan Konflik}

Menyelesaikan sebuah konflik bukanlah hal yang mudah. Untuk bisa menyelesaikan 
permasalahan ini, Partai Nasdem harus bisa menggunakan strategi penyelesaian yang benar benar tepat. Sehingga pada akhirnya, konflik internal tersebut benar benar selesai dan tidak akan muncul kembali dikemudian hari. Untuk mengembalikan citra positif partai Nasdem, harus ada upaya-upaya yang dilakukan agar tidak berdampak negatif dalam pemilu 2014 mendatang. Untuk mengembalikan citra positif Nasdem, Nasdem harus melakukan konsolidasi internal partai untuk memperbaiki struktur kepengurusan partai yang baru. Nasdem juga harus melakukan consensus, dimana pihak-pihak yang sedang bertentangan ber-temu bersama untuk mencari penyelesaian terbaik masalah mereka, dan bukan mencari kemenangan satu pihak saja. Para kaderyang mengundurkan diri adalah kader yang memiliki perbedaan tujuan dan pemikiran dengan Ketua Umum Nasdem yang telah dipilih melalui Kongres Nasdem. Sedangkan kader yang masih bertahan dalam Nasdem adalah para kader yang mendukung kepemimpinan Surya Paloh. Nasdem harus membenahi struktur dan mempertegas tujuan awal dari Nasdem sebagai partai politik sehingga akan terbentuk kesamaan tujuan dan pemikiran antara pemimpin Nasdem dan semua anggotanya, dengan begitu Nasdem bisa meneruskan rencana dan program-program yang telah direncanakan sebelumnya untuk kembali membuat masyarakat kembali percaya dan mendukung Nasdem.

\section{Pengaruh Hari Tanoe Dalam Partai Nasdem}

Mundurnya Hary Tanoe, diikuti oleh beberapa kader seperti Ahmad Rofiq selaku Sekretaris Jendral Nasdem, Wakil Sekretaris Jendral Saiful Haq, dan Ketua Internal DPP Partai Nasdem Endang Tirtana. Selain itu juga terjadi pengunduran diri oleh beberapa kader dari beberapa provinsi yang ada di Indonesia. Hal ini menunjukkan bahwa Hary Tanoe mempunyai pengaruh yang cukup besar dalam pencitraan partai Nasdem, sehingga bisa membuat kader lain mengikuti pengunduran dirinya dari partai Nasdem. Hary Tanoe memiliki peran penting dalam pencitraan Partai Nasdem dan berpengaruh cukup besar dalam perkembangan partai Nasdem. Hary Tanoe yang merupakan pengusaha dianggap mampu memberikan bantuan financial yang besar demi perkembangan Partai Nasdem. Ini merupakan salah satu strategi political marketing yaitu Promosi (promotion) adalah upaya periklanan. Mundurnya Hary Tanoe membuat media yang dimiliki Hary Tanoe tidak lagi banyak menampilkan iklan tentang Partai Nasdem.

\section{Pencitraan Politik Nasdem Pada Pemilihan Legislatif 2014}

Keluarnya Hary Tanoe akan mengganggu pencitraan Nasdem, karena salah satu alat untuk pencitraan politik adalah media massa. Hary Tanoe memiliki jaringan media yang lebih besar dibandingkan dengan Metro Tv dan Media Group yang dimiliki Surya Paloh. Selain itu media massa yang di miliki oleh Hary Tanoe bisa ditonton oleh semua umur, berbeda dengan Metro Tv yang dimiliki Surya Paloh, program yang ditayangkan lebih banyak pada program berita sehingga tidak semua orang tertarik menonton berita di televisi. Konflik internal Nasdem dapat mengganggu pencitraan politik Nasdem dalam pemilu 2014 yang akan datang. Nasdem harus bisa menerapkan strategi terbaik untuk mempertahankan image yang positif menurut Firmanzah agar konflik ini tidak menimbulkan opini negatif dari masyarakat dan mempengaruhi pilihan masyarakat dalam pemilu 2014.

\section{SIMPULAN}

Berdasarkan uraian hasil penelitian dan pembahasan mengenai konflik internal partai Nasdem, maka penulis dapat menarik simpulan sebagai berikut:

1. Konflik internal partai Nasdem merupakan konflik kepentingan yang disebabkan adanya perebutan kursi Ketua Umum Nasdem antara Surya Paloh dan Hary Tanoe Sudibjo. Konflik ini mengakibatkan mundurnya Hary Tanoe dari Partai Nasdem.

2. Konflik internal Nasdemberdampak positif dan negatif. Dampak positifnya yaitu dengan adanya konflik maka akan meningkatkan solidaritas dan rasa kekeluargaan antar kader Nasdem. Sedangkan dampak negatifnya adalah konsentrasi partai yang terpecah untuk menyelesaikan konflik ini. Dampak dalam masyarakat adalah kurang nya rasa kepercayaan masyarakat pada Nasdem sebagai partai baru yang diharapkan bisa membawa perubahan positif. 
3. Upaya yang harus dilakukan Nasdem untuk mengembalikan kepercayaan masyarakat adalah Nasdem harus membenahi struktur dan mempertegas tujuan awal dari Nasdem sehingga akan terbentuk kesamaan tujuan dan pemikiran antara pemimpin Nasdem dan semua anggotanya. Dengan begitu Nasdem bisa meneruskan rencana dan programprogramyangtelah direncanakansebelumnya untuk kembali membuat masyarakat kembali percaya dan mendukung Nasdem.

4. Pengurus Nasdem di beberapa daerah di Indonesia yang mengundurkan diri adalah orang-orang yang menjadi pendukung Hary Tanoe. Hary Tanoe memiliki jaringan media yang luas, sehingga perperan cukup besar dalam memperkenalkan Nasdem pada masyarakat.

5. Konflik Nasdem akan membentuk opini negatif dari masyarakat, dan opini negatif yang tercipta dalam masyarakat dapat mengganggu penciitraan Nasdem pada pemilihan legislatuf 2014.

Berdasarkan simpulan yang telah dikemukakan di atas, maka penulis mengajukan saran:

1. Perlu adanya komunikasi yang baik antar setiap anggota Partai Nasdem agar perbedaan pemikiran bisa di selesaikan dengan baik.

2. Nasdemharusmenunjukkan padamasyarakat bahwa konflik yang terjadi merupakan suatu proses perkembangan Nasdem untuk menjadi Partai ynag lebih baik lagi nantinya.

3. Konflik yang sudah terjadi dalam Partai Nasdem harus diselesaikan secara kekeluargaan agar tidak menimbulkan opini negatif dalam masyarakat.

4. Nasdem harus memaksimalkan media yang dimiliki Surya Paloh untuk lebih memperkenalkan Nasdem pada masyarakat.

5. Nasdem harus membenahi struktur dan mempertegas tujuan awal dari Nasdem sehingga akan terbentuk kesamaan tujuan dan pemikiran antara pemimpin Nasdem dan semua anggotanya. Dengan begitu Nasdem bisa meneruskan rencana dan programprogram yang telah direncanakan sebelumnya untuk kembali membuat masyarakat kembali percaya dan mendukung Nasdem dalam pemilihan legislatif 2014.

\section{DAFTAR PUSTAKA}

Budiardjo, Miriam. 2003. Dasar-Dasar Ilmu Politik. Jakarta: Gramedia Pustaka Utama.

Bungin, Burhan. 2001. Metode Penelitian Kualitatif. Jakarta: Raja Grafindo Persada.

Darmastuti, Ari. dan Tabah Maryanah. 2004. Sistem Kepartaian dan Pemilu di Indonesia. Bandar Lampung: Universitas Lampung.

Djuhandar, Erom. 2005. Sosiologi Politik. Bandar Lampung: Universitas Lampung.

Firmanzah. 2008. Marketing Politik. Jakarta: Yayasan Obor Indonesia.

Handoko, T.Hani. 1999. Manajemen. Yogyakarta: BPFE.

Hasan, Iqbal. 2011. Analisis Data Penelitian Dengan Statistik. Bandung: Bumi Aksara.

http://lampung.tribunnews.com./m/index. $\mathrm{php} / / 2013 / 02 / 07 / \mathrm{dp} 4-k$ ota-metro116.109-jiwa.html. Diunduh pada Hari Kamis, 7 Februari2013.

http://news.detik.com/read/2012/02/09/1 85726/1838800/10/inilah-tahapanpemilu-legislatif-2014. Diunduh pada Hari Rabu, 6 Februari 2013.

http:/politik.kompasiana.com/2010/07/05/ pilkada-lampung-dan-pemenangnyaadalah-golput-185954.htmlDiunduh pada Hari Rabu, 6 Februari 2013.

http://www.gatra.com/fokus-berita/23575perang-petinggi-partai-Nasdem.html / . diunduh pada hari Kamis, 31 Januari 2013.

h t t p : / / w w w m e t r o k o t a . go.id/?page $=$ konten $\& \&$ no $=52$. Diunduh pada tanggal 22 Maret 2013.

http://www.partaiNasdem.org/2011/11/18/ menerka-peluang-partai-Nasdem-dipemilu-2014/. Diunduh pada hari Kamis, 31 Januari 2013 Pukul 20.42 WIB

h t t p : / / w w w.ri m a n e w s . c o m/ $\mathrm{read} / 20120813 / 72281 /$ golkar-menang-dipemilu-2014. Diunduh pada hari Rabu, 6 Febuari 2013. 
h t t p : / / w w w.ri m a n e w s . c o m / $\mathrm{read} / 20130205 / 90876 /$ pasek-smrckonsultan-partai-tertentu-wajarlahdemokrat-jeblok. Diunduh pada hari Rabu, 6 Februari 2013.

http://id.wikipedia.org/wiki/Nasdem. Diunduh pada tanggal 22 Maret 2013.

Huntington, P. Samuel. 1983. Tertib Politik Masyarakat Yang Sedang Berubah. Jakarta: CV Rajawali.

Kartono, Kartini. 2009. Pemimpin dan Kepemimpinan. Jakarta: Rajawali Pers.

Lexy, J. Moeleong. 2004. Metode penelitian Kualitatif. Bandung: Remaja Rosda Karya.

Mastenbroek, W.F.G. 1986. Penanganan Konflik Dan Pertumbuhan Organisasi. Jakarta: Universitas Indonesia.
Mattew, dan Haberman A. Micheal. 1992. Analisis Data Kualitatif. Jakarta: Universitas Indonesia.

Peg, Pickering. 2006. How to Manage Conflict. Jakarta: Erlangga.

Robbins, P. Stephen. 2002. Perilaku Organisasi. Jakarta: Erlangga.

Soekamto, Soerjono. 1984. Sosiologi Suatu Pengantar. Jakarta: Raja Gravindo Persada.

Sugiono. 2008. Metode Penelitian Kualitatif dan Kuantitatif. Bandung: Alfabeta.

Surbakti, Ramlan. 1992. Memahami Ilmu Politik. Jakarta: Grasindo.

Undang-Undang Republik Indonesia Nomor 2 tahun 2011 tentang Partai Politik. 